\title{
Microbacterium yannicii sp. nov., isolated from Arabidopsis thaliana roots
}

\author{
Silke Karojet, Sabine Kunz† and Joost T. van Dongen
}

\author{
Correspondence \\ Joost T. van Dongen \\ dongen@mpimp-golm.mpg.de
}

\author{
Max Planck Institute of Molecular Plant Physiology, Department of Organelle Biology, \\ Biotechnology and Molecular Ecophysiology, Energy Metabolism Research Group, \\ D-14476 Potsdam-Golm, Germany
}

\begin{abstract}
Bacterial strain $\mathrm{G} 72^{\top}$ was isolated from surface-sterilized roots of Arabidopsis thaliana growing in its natural habitat. This Gram-positive, rod-shaped, non-motile, microaerophilic and aerobically growing isolate was characterized by using a polyphasic approach. On the basis of 16S rRNA gene sequence similarity, strain $\mathrm{G} 72^{\top}$ belongs to the genus Microbacterium. However, reassociation values in a DNA-DNA hybridization analysis with closely related strains were between 45.1 and $15.9 \%$. The DNA G + C content was 70.1 mol\%. Strain $\mathrm{G}^{\top} 2^{\top}$ possessed a peptidoglycan type based on $B 2 \beta$ with partial substitution of glutamic acid by 3-hydroxy glutamic acid (Glu/Hyg-Gly-D-Orn). The isolate contained MK-13, MK-12 and MK-11 as major respiratory quinones and anteiso- $C_{15: 0}$, anteiso- $C_{17: 0}$ and iso- $C_{16: 0}$ as predominant fatty acids. The major polar lipids were diphosphatidylglycerol, phosphatidylglycerol and three unidentified glycolipids. Based on its physiological and biochemical traits, as well as genotypic results, strain $\mathrm{G} 72^{\top}$ is considered to represent a novel species, for which the name Microbacterium yannicii sp. nov. is proposed. The type strain is $\mathrm{G} 72^{\top}\left(=\mathrm{DSM} 23203^{\top}=\mathrm{LMG} 25521^{\top}\right)$.
\end{abstract}

Plants are generally colonized by many microbes. Apart from pathogenic bacteria, there are also bacteria that improve the growth and health of their host plants (Lugtenberg \& Kamilova, 2009). To date, the beneficial effects of bacteria on plant growth have been mainly investigated in crop plants, but little is known about the molecular and physiological mechanisms that ultimately result in growth promotion. In our study, we isolated bacteria from roots of Arabidopsis thaliana, which is a model organism in plant research. Therefore, a wide array of molecular and genetic techniques is available to perform further research, which should lead to a better understanding of the mechanism leading to bacterially induced plant growth promotion. Here we describe the isolation and characterization of a bacterial strain, designated $\mathrm{G} 72^{\mathrm{T}}$, isolated from surface-sterilized roots of $A$. thaliana growing in the field, with the subsequent aim to investigate its effect on plant growth. As a result of pheno- and genotypic characterization, we propose that strain $\mathrm{G} 72^{\mathrm{T}}$ represents a novel species of the genus Microbacterium, for which we propose the name Microbacterium yannicii sp. nov.

Strain $\mathrm{G} 72^{\mathrm{T}}$ was isolated from roots of $A$. thaliana (thale cress) collected from a field in Golm (52 $24^{\prime} 57^{\prime \prime} \mathrm{N} 12^{\circ} 58^{\prime}$

tPresent address: Department of Plant Physiology, Plant Science Centre, Umeå University, 90187 Umeå, Sweden.

The GenBank/EMBL/DDBJ accession number for the 16S rRNA gene sequence of strain $G 72^{\top}$ is FN547412.

A supplementary figure is available with the online version of this paper.
18" E, Potsdam, Germany; soil texture: loamy sand). Roots were surface-sterilized with $70 \%$ ethanol for $1 \mathrm{~min}$ and $2.5 \%$ sodium hypochlorite for $3 \mathrm{~min}$. After rinsing three times in sterile distilled water, roots were ground using a sterile mortar and pestle. The ruptured root tissue was incubated in 1/4 strength Ringer solution (Merck) for $45 \mathrm{~min}$ with shaking at room temperature. After $5 \mathrm{~min}$ of sedimentation, dilutions of the suspension were spread on modified tryptic soy agar (TSA) medium adapted from the method of Jacxsens et al. (2003). To simulate nutrient availability in Arabidopsis, this medium contained $50 \%$ Arabidopsis leaf juice, $50 \%$ tryptic soy broth (TSB; SIFIN) and $1 \%$ agar $(\mathrm{w} / \mathrm{v})$ in total. Leaf juice was obtained from greenhouse grown $A$. thaliana plants and heated for $2 \mathrm{~h}$ at $80{ }^{\circ} \mathrm{C}$ to denature enzymes. The filtrate was mixed with an equal volume of TSB. After addition of the required amount of agar, the solution was autoclaved for $15 \mathrm{~min}$ at $121{ }^{\circ} \mathrm{C}$. Single colonies were selected after 3 days of growth at $16{ }^{\circ} \mathrm{C}$. Further cultivation was performed on TSA or TSB at $16{ }^{\circ} \mathrm{C}$ unless otherwise stated.

To determine the 16S rRNA gene sequence, chromosomal DNA was extracted from the bacterial isolate and purified using the PureLink genomic DNA mini kit (Invitrogen) according to the manufacturer's instructions. The gene was amplified by PCR with the universal primers P0 and P6 as described by Ventura et al. (2001) and the Advantage HF2 PCR kit (Clontech). Purified PCR products were sequenced by AGOWA (Berlin, Germany). The resulting sequence of 1466 base pairs of the 16S rRNA gene of strain $\mathrm{G} 72^{\mathrm{T}}$ was 
used to perform a similarity search against entries in the EzTaxon database of type strains of prokaryotic species with validly published names (www.eztaxon.org; Chun et al., 2007) by means of the BLAST (Altschul et al., 1997) and megaBLAST (Zhang et al., 2000) programs. Strain G72 showed highest pairwise sequence similarity to taxa of the genus Microbacterium. A similarity of $98.427 \%$ was obtained with Microbacterium hominis (IFO $15708^{\mathrm{T}}$; AB004727), $98.339 \%$ with Microbacterium insulae (DS-66 ${ }^{\mathrm{T}}$; EU239498) and $98.292 \%$ with Microbacterium thalassium (IFO $16060^{\mathrm{T}}$; AB004713). Phylogenetic and molecular evolutionary analyses were carried out using the MEGA4 software package (Kumar et al., 1994; Tamura et al., 2007). Multiple sequence alignment was performed with CLUSTAL $\mathrm{X}$, version 2.0.11 (Larkin et al., 2007). A phylogenetic tree (Supplementary Fig. S1, available in IJSEM Online) based on 16S rRNA gene sequences of accepted type strains of the genus Microbacterium was generated by applying the neighbourjoining algorithm (Saitou \& Nei, 1987). The length of the sequences used to reconstruct the phylogenetic tree was $1166 \mathrm{nt}$. Evolutionary distances were computed using the maximum composite likelihood method (Tamura et al., 2004) and bootstrap analysis (Felsenstein, 1985) with 1000 resamples was used to evaluate the tree topology. The $16 \mathrm{~S}$ rRNA gene sequence of Arthrobacter globiformis was used as an out group. A detailed representation of the cluster comprising M. yannicii sp. nov. and its closest phylogenetic neighbours is shown in Fig. 1. On the basis of this phylogenetic analysis, the type strains of the species Microbacterium trichothecenolyticum, $M$. insulae and $M$. hominis were selected for comparative analyses.

Analysis of biochemical and morphological traits of strain $G 72^{\mathrm{T}}$ was carried out by the Identification Service of the Deutsche Sammlung von Mikroorganismen und Zellkulturen (DSMZ, Braunschweig, Germany).

The cell-wall peptidoglycan structure was analysed by means of TLC, 2D-TLC, GS and GC/MS (Schleifer, 1985; MacKenzie, 1987; Groth et al., 1996). The total hydrolysate $\left(4 \mathrm{M} \mathrm{HCl}, 100{ }^{\circ} \mathrm{C}, 16 \mathrm{~h}\right.$ ) contained ornithine, alanine, glycine, homoserine and small amounts of glutamic acid. Using GC/MS analysis, high amounts of 3-hydroxyglutamic acid (Hyg) were detected. According to Schleifer \& Kandler (1972), these data suggested that the peptidoglycan structure of the isolate was of type B2 $\beta$ with partial substitution of glutamic acid by 3-hydroxyglutamic acid (Glu/Hyg-Gly-DOrn).

For cellular fatty acid analysis, cells were grown on TSA for 2 days at $30{ }^{\circ} \mathrm{C}$. Fatty acid methyl esters were obtained from $40 \mathrm{mg}$ of cells, scraped from Petri dishes, by saponification, methylation and extraction using minor modifications of the methods of Miller (1982) and Kuykendall et al. (1988). Extracts were separated and analysed using the Microbial Identification System (MIS; MIDI), which consisted of a gas chromatograph $(6890 \mathrm{~N}$; Agilent Technologies) equipped with a 5\% phenyl-methyl silicone capillary column, a flame-ionization detector (17683A; Agilent Technologies) and the MIDI database TSBA 4.10. Peaks were automatically integrated and fatty acid names and percentages calculated by the Sherlock MIS 6.1 software. As major compounds of the fatty acid profile, anteiso- $\mathrm{C}_{15: 0}(44.76 \%)$, anteiso- $\mathrm{C}_{17: 0}(29.45 \%)$ and iso$\mathrm{C}_{16: 0}(13.50 \%)$ were identified. This analysis was done as a comparative study for which the fatty acid profiles of strain $\mathrm{G} 72^{\mathrm{T}}$ and its closest phylogenetic neighbours were determined under the same conditions (Table 1).

Respiratory lipoquinones and polar lipids were extracted from $100 \mathrm{mg}$ freeze-dried cell material using the twostage method described by Tindall (1990a, b). Respiratory quinones were extracted using methanol/hexane (Tindall, 1990a, b), followed by phase separation into hexane. Polar lipids were extracted by adjusting the remaining methanol/ $0.3 \%$ aqueous $\mathrm{NaCl}$ phase (containing the cell debris) to give a chloroform/methanol $/ 0.3 \%$ aqueous $\mathrm{NaCl}$ mixture of $1: 2: 0.8$ (by vol.). The extraction solvent was stirred overnight and the cell debris pelleted by centrifugation. Polar lipids were recovered into the chloroform phase by adjusting the chloroform $/$ methanol $/ 0.3 \%$ aqueous $\mathrm{NaCl}$ mixture to a ratio of $1: 1: 0.9$ (by vol.). Respiratory lipoquinones were separated into their different classes (menaquinones, ubiquinones, etc.) by thin layer chromatography on silica gel (Macherey-Nagel art. no. 805 023), using hexane/tert-butylmethylether $(9: 1, \mathrm{v} / \mathrm{v})$ as

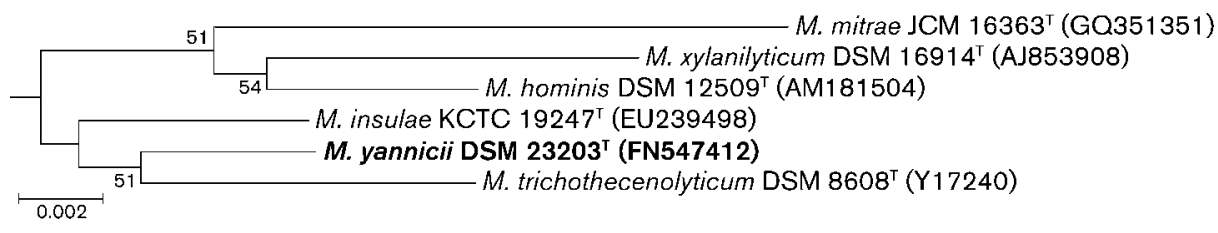

Fig. 1. Phylogenetic tree based on $16 \mathrm{~S}$ rRNA gene sequences showing the position of strain $\mathrm{G} 72^{\top}$ among closely related type strains of the genus Microbacterium. The tree was reconstructed by the neighbour-joining method. Bootstrap values $>50 \%$ based on 1000 replications are shown at branching points. The tree is drawn to scale, with branch lengths in the same units as those of the evolutionary distances used to infer the phylogenetic tree. Evolutionary distances were computed using the maximum composite likelihood method. Bar, 2 substitutions per 1000 nt positions. GenBank accession numbers for the $16 \mathrm{~S}$ rRNA gene sequence of each reference species are shown in parentheses. The sequence length used to reconstruct the phylogenetic tree was 1166 nt. An extended version of this tree is available as Supplementary Figure S1. 
Table 1. Fatty acid profiles of strain $G 72^{\top}$ and the three most closely related type strains

Strains: 1, Microbacterium yannicii sp. nov. $\mathrm{G}^{\mathrm{T}}{ }^{\mathrm{T}} ; 2, \quad M$. trichothecenolyticum DSM $8608^{\mathrm{T}}$; 3, M. insulae DSM $23024^{\mathrm{T}}$; 4, M. hominis DSM $12509^{\mathrm{T}}$. Values are percentages of total fatty acids. -, not detected or $<1 \%$.

\begin{tabular}{|c|c|c|c|c|}
\hline Fatty acid & 1 & 2 & 3 & 4 \\
\hline iso- $\mathrm{C}_{14: 0}$ & 0.83 & 0.34 & 0.79 & 0.61 \\
\hline iso- $\mathrm{C}_{15: 0}$ & 4.88 & 2.10 & 3.69 & 3.12 \\
\hline anteiso- $\mathrm{C}_{15: 0}$ & 44.76 & 45.76 & 47.57 & 41.51 \\
\hline iso- $\mathrm{C}_{16: 0}$ & 13.50 & 14.40 & 13.08 & 18.55 \\
\hline$C_{16: 0}$ & 0.81 & 0.87 & 1.34 & 5.31 \\
\hline iso- $\mathrm{C}_{17: 0}$ & 3.57 & 6.85 & 7.91 & 1.27 \\
\hline anteiso- $\mathrm{C}_{17: 0}$ & 29.45 & 22.38 & 17.62 & 28.63 \\
\hline$C_{17: 0}$ & 0.10 & 0.19 & 0.22 & 0.75 \\
\hline iso- $\mathrm{C}_{18: 0}$ & 1.11 & 3.11 & 5.60 & - \\
\hline $\mathrm{C}_{18: 0}$ & 0.73 & 2.60 & 0.92 & - \\
\hline anteiso- $C_{19: 0}$ & 0.18 & 1.40 & 0.77 & - \\
\hline
\end{tabular}

solvent. UV absorbing bands corresponding to the different quinone classes (e.g. menaquinones or ubiquinones) were removed from the plate and further analysed by HPLC. This step was carried out on a LDC Analytical (Thermo Separation Products) HPLC fitted with a reverse phase column (Macherey-Nagel; $2 \mathrm{~mm} \times 125 \mathrm{~mm}, 3 \mu \mathrm{m}$, RP18) using methanol/heptane 9:1 (v/v) as the eluent. Respiratory lipoquinones were detected at $269 \mathrm{~nm}$. The predominant quinones detected in strain $\mathrm{G} 72^{\mathrm{T}}$ were MK13 (major component), MK-12 and MK-11. Polar lipids were separated by two-dimensional silica gel thin layer chromatography (Macherey-Nagel art. no. 818 135). The first direction was developed in chloroform/methanol/ water $(65: 25: 4$, by vol.), and the second in chloroform/ methanol/acetic acid/water $(80: 12: 15: 4$, by vol.). Total lipid material and specific functional groups were detected using dodecamolybdophosphoric acid (total lipids), Zinzadze reagent (phosphate), ninhydrin (free amino groups), periodate-Schiff ( $\alpha$-glycols), Dragendorff (quaternary nitrogen) and $\alpha$-naphthol/sulphuric acid (glycolipids). Full details are given by Tindall et al. (2007). The major polar lipids were diphosphatidylglycerol, phosphatidylglycerol and three unidentified glycolipids.

Carbon-source utilization, urease and arginine dihydrolase activity, and hydrolysis of gelatin were determined by using API $20 \mathrm{NE}$ and API Coryne galleries according to the manufacturer's instructions (bioMérieux). Hydrolysis of starch and Tween 80 and the assimilation of acetate, fumarate and DL-lactate were assayed as described by Stanier et al. (1966). Aerotolerance was determined as described by Brewer (1940). All other analyses were performed according to Reddy et al. (2007). Cell morphology and motility were observed under a phase-contrast microscope (Axioskop; Zeiss) at $\times 1000$ magnification. Results are summarized in the species description and were compared with biochemical traits of phylogenetically related type strains of species of the genus Microbacterium grown and analysed under the same conditions (Table 2). Strain $\mathrm{G} 72^{\mathrm{T}}$ differs in several biochemical properties from the most closely related species.

To determine the $\mathrm{G}+\mathrm{C}$ content, genomic DNA was isolated and purified according to the method of Cashion et al. (1977). After subsequent enzymic degradation, deoxyribonucleotides were analysed by reversed-phase HPLC. The $\mathrm{G}+\mathrm{C}$ content was calculated as described by Mesbah et al. (1989) and was $70.1 \mathrm{~mol} \%$.

For DNA-DNA hybridization experiments, the most closely related type strains, $M$. trichothecenolyticum, $M$. insulae and $M$. hominis, were chosen according to the phylogenetic analysis of $16 \mathrm{~S}$ rRNA gene sequences (Fig. 1). DNA was isolated using a French pressure cell (Thermo Spectronic) and was purified by chromatography on hydroxyapatite as described by Cashion et al. (1977). DNA-DNA hybridization was carried out as described by De Ley et al. (1970) under consideration of the modifications described by Huss et al. (1983) using a model Cary

Table 2. Biochemical characteristics that differentiate strain $\mathrm{G} 72^{\top}$ from its nearest phylogenetic neighbours

Strains: 1, Microbacterium yannicii sp. nov. $\mathrm{G} 72^{\mathrm{T}} ; 2, \quad M$. trichothecenolyticum DSM $8608^{\mathrm{T}}$; 3, M. insulae DSM $23024^{\mathrm{T}}$; 4, M. hominis DSM $12509^{\mathrm{T}}$. +, Positive; - , negative; $\mathrm{w}$, weakly positive. All strains were positive for Gram reaction, $\alpha$ - and $\beta$-glucosidase, $N$ acetyl- $\beta$-glucosaminidase, $\mathrm{H}_{2} \mathrm{~S}$ formation, hydrolysis of gelatin and starch, and assimilation of sucrose. All strains were negative for urease, arginine dihydrolase, and assimilation of phenylacetate, ribose, lactose and glycogen.

\begin{tabular}{|c|c|c|c|c|}
\hline Characteristic & 1 & 2 & 3 & 4 \\
\hline Growth in $2 \% \mathrm{NaCl}$ & - & + & + & + \\
\hline Growth at $37{ }^{\circ} \mathrm{C}$ & $\mathrm{w}$ & + & + & + \\
\hline \multicolumn{5}{|l|}{ Enzymic activity } \\
\hline Pyrazinamidase & + & - & - & + \\
\hline Pyrrolidonyl arylamidase & - & + & - & - \\
\hline Alkaline phosphatase & - & + & - & - \\
\hline$\beta$-Glucuronidase & + & - & - & - \\
\hline$\beta$-Galactosidase & + & + & - & + \\
\hline Catalase & + & + & $\mathrm{w}$ & + \\
\hline Voges-Proskauer test & - & - & - & + \\
\hline Nitrate reduction & - & + & - & - \\
\hline \multicolumn{5}{|l|}{ Hydrolysis of: } \\
\hline Tween 80 & + & + & - & - \\
\hline \multicolumn{5}{|l|}{ Assimilation of: } \\
\hline Sodium acetate & + & + & + & - \\
\hline DL-Lactate & + & + & - & - \\
\hline DL-Malate & - & + & - & - \\
\hline Fumarate & - & + & + & - \\
\hline L-Arabinose & + & + & + & - \\
\hline Glucose & w & + & + & + \\
\hline Mannitol & - & - & - & + \\
\hline Maltose & $\mathrm{w}$ & $\mathrm{w}$ & + & + \\
\hline
\end{tabular}


100 Bio UV/VIS spectrometer equipped with a Peltierthermostat $6 \times 6$ multicell changer and a temperature controller with in-situ temperature probe (Varian). This analysis showed a genetic relatedness of $45.1 \pm 4.2 \%$ (mean \pm standard deviation) between strain $\mathrm{G}^{2}{ }^{\mathrm{T}}$ and $M$. trichothecenolyticum DSM $8608^{\mathrm{T}}, 31.2 \pm 6.3 \%$ with $M$. insulae DSM $23024^{\mathrm{T}}$ and $15.9+3.4 \%$ with $M$. hominis DSM $12509^{\mathrm{T}}$. These degrees of genomic relatedness were well below the limit of $70 \%$ for species definition recommended by Wayne et al. (1987).

The data presented are consistent with the classification of strain $\mathrm{G}^{\mathrm{T}}{ }^{\mathrm{T}}$ in the genus Microbacterium. However, on the basis of biochemical and genetic analyses this isolate is clearly capable of being differentiated from the closest related species. Therefore, strain $\mathrm{G} 72^{\mathrm{T}}$ is considered to represent an independent species of the genus Microbacterium, for which we propose the name Microbacterium yannicii sp. nov.

\section{Description of Microbacterium yannicii sp. nov.}

Microbacterium yannicii (yan.ni'ci.i. N.L. gen. masc. n. yannicii of Yannic, in honour of the inspirational contribution of Yannic Karojet to the research project that led to the isolation and identification of the bacterial species).

Cells are Gram-positive, the $\mathrm{KOH}$ string test is negative and aminopeptidase activity is not detected. Colonies are 1$2 \mathrm{~mm}$ in diameter after $72 \mathrm{~h}$ of incubation at $16{ }^{\circ} \mathrm{C}$ on TSA, circular, low convex with entire margins, moist and with a transparent milky colour. Colony colour changes to an opaque, intense yellow after 10 days. Cells are non-motile, irregular short rods, $0.5-0.6 \times 1.5-3.0 \mu \mathrm{m}$ in size. Exhibits micro-aerophilic and aerobic growth. Temperature range for growth is from 4 to $37{ }^{\circ} \mathrm{C}$. Growth does not occur in the presence of $2 \%(\mathrm{w} / \mathrm{v}) \mathrm{NaCl}$. Cells demonstrate enzymic activity of pyrazinamidase, $\beta$-glucuronidase, $\beta$-galactosidase, $\alpha$ - and $\beta$-glucosidase, $N$-acetyl- $\beta$-glucosaminidase and catalase, but no activity of pyrrolidonyl arylamidase, alkaline phosphatase, urease or arginine dihydrolase. VogesProskauer test result is negative. $\mathrm{H}_{2} \mathrm{~S}$ is produced. Nitrate is not reduced. Gelatin, starch and Tween 80 are hydrolysed. Sodium acetate, DL-lactate, L-arabinose and sucrose are utilized as substrates, but not DL-malate, fumarate, sodium propionate, citrate, phenylacetate, ribose, mannitol, lactose or glycogen. Glucose and maltose are poor substrates. The peptidoglycan is of type $\mathrm{B} 2 \beta$ with partial substitution of glutamic acid by 3 -hydroxyglutamic acid (Glu/Hyg-Gly-DOrn). The major fatty acids are anteiso- $\mathrm{C}_{15: 0}$, anteiso- $\mathrm{C}_{17: 0}$ and iso- $\mathrm{C}_{16: 0}$ and the polar lipid profile consists of the major lipids diphosphatidylglycerol, phosphatidylglycerol and three unidentified glycolipids. Predominant menaquinones are MK-13, MK-12 and MK-11. The G $+\mathrm{C}$ content of the genomic DNA is $70.1 \mathrm{~mol} \%$.

The type strain, $\mathrm{G} 72^{\mathrm{T}}\left(=\mathrm{DSM} 23203^{\mathrm{T}}=\mathrm{LMG} 25521^{\mathrm{T}}\right)$, was isolated from roots of Arabidopsis thaliana plants that were growing in the fields of Golm, in the area around Potsdam, Germany.

\section{Acknowledgements}

Dr Susanne Verbarg of the DSMZ (Deutsche Sammlung von Mikroorganismen und Zellkulturen, Braunschweig, Germany) is kindly acknowledged for her help with chemotaxonomic and DNADNA hybridization analysis and the discussion of the results. We thank Professor J.P. Euzéby for his help with the Latin construction of the species name.

\section{References}

Altschul, S. F., Madden, T. L., Schäffer, A. A., Zhang, J., Zhang, Z., Miller, W. \& Lipman, D. J. (1997). Gapped BLAST and PSI-BLAST: a new generation of protein database search programs. Nucleic Acids Res 25, 3389-3402.

Brewer, J. H. (1940). Clear liquid mediums for the "aerobic" cultivation of anaerobes. J Am Med Assoc 115, 598-600.

Cashion, P., Holder-Franklin, M. A., McCully, J. \& Franklin, M. (1977). A rapid method for the base ratio determination of bacterial DNA. Anal Biochem 81, 461-466.

Chun, J., Lee, J.-H., Jung, Y., Kim, M., Kim, S., Kim, B. K. \& Lim, Y. W. (2007). EzTaxon: a web-based tool for the identification of prokaryotes based on $16 \mathrm{~S}$ ribosomal RNA gene sequences. Int J Syst Evol Microbiol 57, 2259-2261.

De Ley, J., Cattoir, H. \& Reynaerts, A. (1970). The quantitative measurement of DNA hybridization from renaturation rates. Eur $J$ Biochem 12, 133-142.

Felsenstein, J. (1985). Confidence limits on phylogenies: an approach using the bootstrap. Evolution 39, 783-791.

Groth, I., Schumann, P., Weiss, N., Martin, K. \& Rainey, F. A. (1996). Agrococcus jenensis gen. nov., sp. nov., a new genus of actinomycetes with diaminobutyric acid in the cell wall. Int J Syst Bacteriol 46, 234239.

Huss, V. A. R., Festl, H. \& Schleifer, K. H. (1983). Studies on the spectrophotometric determination of DNA hybridization from renaturation rates. Syst Appl Microbiol 4, 184-192.

Jacxsens, L., Devlieghere, F., Ragaert, P., Vanneste, E. \& Debevere, J. (2003). Relation between microbiological quality, metabolite production and sensory quality of equilibrium modified atmosphere packaged fresh-cut produce. Int J Food Microbiol 83, 263-280.

Kumar, S., Tamura, K. \& Nei, M. (1994). MEGA: molecular evolutionary genetics analysis software for microcomputers. Comput Appl Biosci 10, 189-191.

Kuykendall, L. D., Roy, M. A., O'Neill, J. J. \& Devine, T. E. (1988). Fatty acids, antibiotic resistance, and deoxyribonucleic acid homology groups of Bradorhizobium japonicum. Int J Syst Bacteriol 38, 358-361.

Larkin, M. A., Blackshields, G., Brown, N. P., Chenna, R., McGettigan, P. A., McWilliam, H., Valentin, F., Wallace, I. M., Wilm, A. \& other authors (2007). CLUSTAL W and CLUSTAL_X version 2.0. Bioinformatics 23, 2947-2948.

Lugtenberg, B. \& Kamilova, F. (2009). Plant-growth-promoting rhizobacteria. Annu Rev Microbiol 63, 541-556.

MacKenzie, S. L. (1987). Gas chromatographic analysis of amino acids as the N-heptafluorobutyryl isobutyl esters. J Assoc Off Anal Chem 70, 151-160.

Mesbah, M., Premachandran, U. \& Whitman, W. B. (1989). Precise measurement of the $\mathrm{G}+\mathrm{C}$ content of deoxyribonucleic acid by highperformance liquid chromatography. Int J Syst Bacteriol 39, 159-167.

Miller, L. T. (1982). Single derivatization method for routine analysis of bacterial whole-cell fatty acid methyl esters, including hydroxy acids. J Clin Microbiol 16, 584-586. 
Reddy, C. A., Beveridge, T. J., Breznak, J. A., Marzluf, G. A., Schmidt, T. M. \& Snyder, L. R. (editors) (2007). Methods for General and Molecular Microbiology, 3rd edn. Washington, DC: American Society for Microbiology.

Saitou, N. \& Nei, M. (1987). The neighbor-joining method: a new method for reconstructing phylogenetic trees. Mol Biol Evol 4, 406425.

Schleifer, K. H. (1985). Analysis of the chemical composition and primary structure of murein. Methods Microbiol 18, 123-156.

Schleifer, K. H. \& Kandler, O. (1972). Peptidoglycan types of bacterial cell walls and their taxonomic implications. Bacteriol Rev 36, 407-477.

Stanier, R. Y., Palleroni, N. J. \& Doudoroff, M. (1966). The aerobic pseudomonads: a taxonomic study. J Gen Microbiol 43, 159-271.

Tamura, K., Nei, M. \& Kumar, S. (2004). Prospects for inferring very large phylogenies by using the neighbor-joining method. Proc Natl Acad Sci U S A 101, 11030-11035.

Tamura, K., Dudley, J., Nei, M. \& Kumar, S. (2007). MEGA4: molecular evolutionary genetics analysis (MEGA) software version 4.0. Mol Biol Evol 24, 1596-1599.
Tindall, B. J. (1990a). A comparative study of the lipid composition of Halobacterium saccharovorum from various sources. Syst Appl Microbiol 13, 128-130.

Tindall, B. J. (1990b). Lipid composition of Halobacterium lacusprofundi. FEMS Microbiol Lett 66, 199-202.

Tindall, B. J., Sikorski, J., Smibert, R. M. \& Krieg, N. R. (2007). Phenotypic characterization and the principles of comparative systematics. In Methods for General and Molecular Microbiology, 3rd edn, pp. 330-393. Edited by C. A. Reddy, T. J. Beveridge, J. A. Breznak, G. A. Marzluf, T. M. Schmidt \& L. R. Snyder. Washington, DC: American Society for Microbiology.

Ventura, M., Elli, M., Reniero, R. \& Zink, R. (2001). Molecular microbial analysis of Bifidobacterium isolates from different environments by the species-specific amplified ribosomal DNA restriction analysis (ARDRA). FEMS Microbiol Ecol 36, 113-121.

Wayne, L. G., Brenner, D. J., Colwell, R. R., Grimont, P. A. D., Kandler, O., Krichevsky, L., Moore, L. H., Moore, W. C., Murray, R. G. E. \& other authors (1987). Report of the ad hoc committee on reconciliation of approaches to bacterial systematics. Int J Syst Bacteriol 37, 463-464.

Zhang, Z., Schwartz, S., Wagner, L. \& Miller, W. (2000). A greedy algorithm for aligning DNA sequences. J Comput Biol 7, 203-214. 